Perbaikan jurnal pertemuan ke 10

\title{
KEDEKATAN HUBUNGAN MASYARAKAT DENGAN LINGKUNGAN ALAM
}

MONIKA SARI

1920701022

KOMUNIKASI LINGKUNGAN

ILKOM A (2019)

Kedekatan hubungan masyarakat dengan lingkungan alam adalah fakta yang tidak terbantahkan. Sejak dari adanya masyarakat di sebuah wilayah, bisa dipastikan tandatanda dan ciri-ciri alam sudah dipahami dan dipelajari oleh kelompok tersebut. Terutama sekali bagi komunitas masyarakat tradisional, tanda-tanda yang datang dari alam bahkan diaplikasikan dalam berbagai bentuk ritual dan tradisi.

Merenungi dan mencermati fenomena alam bisa membuat manusia kaya akan pengetahuan dan pengalaman. Begitupula bila manusia mengambil hikmah dari sekian banyak peristiwa menimpanya, sehingga lambat laun dapat membuat manusia lebih arif dan bijaksana. Menjadi seorang yang arif dan bijaksana memerlukan kelapangan dan keterbukaan hati, serta kejernihan keluwesan berfikir. Hal ini tidak akan dipunyai oleh setiap/sembarang orang, hanya mereka yang pernah mengalami pahit-getirnya hiduplah yang dapat menghayati-merasakannya.

Dalam jurnal artikel (Soeharto \& Unisba, 2004) Ada berbagai makna yang tersurat maupun tersirat dari alam bagi kelestarian kehidupan manusia, namun ada dan menemukan satu "keindahan" bila melaluinya dengan kebersihan-keikhlasan jiwa. Bila ada keindahan yang menjadikan pedoman kebaikan bagi kehidupan umat manusia, 
mengapa tidak menjadikan "keindahan" itu sebuah kajian yang bisa membuat kehidupan lebih dewasa, arif, bijaksana dan maju.

Keindahan adalah kesatuan daripada bentuk formal hubungan antara rasa dan persepsi.

Hubungan, mempunyai arti dan fungsi yang sangat luas dan beraneka ragam, bisa terjadi pada subjek/objek (unsur, komponen apapun). Dalam uraian ini "hubungan timbal balik" melihat pada dampak/pengaruh yang terjadi (fungsional, determinan, aksi dan lain-lain). Uraian pembahasan pada diskusi ini mengarah pada pengertian ;

a. Dampak hubungan (timbal balik) manusia dan alam pada "hubungan" yang saling merabuk (vertelizing) disatu sisi, berlandaskan hukumnya (sunnatullah) masing-masing, dan atau,

b. Dalam hubungan yang saling menghilangkan, mematikan, menyimpang/keluar dari sunnatullah masing-masing manusia dengan alam,

c. Hubungan lebih mendalam dikenal dengan ekosistem (lingkungan hidup)

Terjadinya suatu hubungan yang indah (nikmat, tenang dan sejuk), dan lestari secara (tumbuh berkembang dan berkelanjutan) sinergi. (Soeharto \& Unisba, 2004)

Dikutip dari jurnal artikel (Yenrizal Y, 2016) Keterikatan hubungan dengan alam yang kemudian diwujudkan dalam bentuk berbagai aktifitas, juga tampak dari bagaimana komunitas masyarakat di Pagar Alam, Sumsel, yang mampu membangun dan menata rumah-rumahnya sehingga menjadi ramah lingkungan, tahan gempa, dan tidak merusak tatanan yang ada. Dalam bahasa Sosiologi, ini kerap disebut juga dengan kearifan lokal (local wisdom).

Memahami struktur alam memang menjadi kata kunci bagi tertatanya sebuah kehidupan yang stabil dan minim persoalan bencana alam. Hal ini dilakukan dengan sebuah prasyarat bahwa lingkungan dan manusia adalah satu kesatuan yang tidak bisa dipisahkan. Melawan struktur dan tipe alam, tidak akan pernah menguntungkan manusia, karena itu yang terbaik adalah bersahabat atau memahami ritme alam. Ini yang disebut oleh AT Rambo sebagai istilah etnoekologi, atau memandang alam dari sudut pandang manusia yang merupakan satu kesatuan tak terpisahkan. Sudut 
pandang ini bukan dalam konteks antroposentris, tetapi ada kesatuan yang tak terpisahkan.(Yenrizal Y, 2016)

Salah satu kelompok yang memiliki sudut pandang khusus ini dan terikat secara jelas dengan lingkungan setempat, bisa dilihat dari aktifitas masyarakat Desa Karang Anyar, Kecamatan Sumber Marga Telang, Kabupaten Banyuasin, Sumatera Selatan. Desa ini adalah desa tua, yang diperkirakan masyarakat sudah terbentuk sejak tahun 1900-an. Posisinya berada persis di pinggiran Sungai Telang, mengikuti lekuk sungai, dan menjadikan sungai sebagai sarana transportasi utama. Hanya belakangan barulah dibuka jalur jalan darat sehingga sungai tidak lagi menjadi prioritas. Kendati berada persis dipinggir sungai, dimana arusnya sering sekali

meluap masuk ke wilayah pemukiman penduduk, tetapi tidak pernah dipermasalahkan. Hunian dan aktifitas penduduk tidak terganggu, bahkan menurut keterangan penduduk, dari dulu sampai sekarang tetap seperti itu. Tidak pernah luapan air melebihi batas yang sudah dirasakan selama ini oleh penduduk.

\section{Kesimpulan}

Kedekatan hubungan masyarakat dengan lingkungan alam adalah fakta yang tidak terbantahkan. Ada berbagai makna yang tersurat maupun tersirat dari alam bagi kelestarian kehidupan manusia, namun ada dan menemukan satu "keindahan" bila melaluinya dengan kebersihan-keikhlasan jiwa.

\section{DAFTAR PUSTAKA}

Yenrizal, Y. (2016) VOL. 05. Sungai dalam pemaknaan masyarakat pedesaan studi etnologi komunikasi pada masyarakat des karang Anyar, Banyuasin, Sumatera Selatan. NIZHAM, 11

https://scholar.google.co.id/citations?user=MYziDiwAAAAJ\&hl=id\#d=gs md citad\&u=\%2Fcitations\%3Fview op\%3Dview citation\%26hl\%3Did\%26user\%3DMYziDiwAAAAJ\%26citation fo r view\%3DMYziDiwAAAAJ\%3AljCSPb-OGe4C\%26tzom\%3D-420

Soeharto, B., \& Unisba, B. (2004). Prof. Bohar Soeharto adalah guru Besar Unisba, tahun 1996 - 1998. XX(1), 26-34. 
